\title{
Achievement emotions, epistemic curiosity, and graded performance of undergraduate students in English preparatory classes \\ Alev Elmalı Özsaray ${ }^{* a}$, Altay Eren ${ }^{* * b}$ \\ ${ }^{a}$ Hacettepe University, School of Foreign Languages, Ankara/Turkey \\ ${ }^{\mathrm{b}}$ Bolu Abant İzzet Baysal University, Faculty of Education, Bolu /Turkey
}

Article Info

DOI: $10.31704 /$ ijocis.2018.003

Article History:

Received 14 November 2017

Revised 01 May 2018

Accepted 23 May 2018

Online $\quad 30$ June 2018

Keywords:

Graded performance,

Epistemic curiosity,

Achievement emotions.

\section{Abstract}

The aim of the study was to examine the relationships between achievement emotions, epistemic curiosity, and graded performance regarding English courses of undergraduate students in English preparatory classes. Exploratory correlational design was adopted in the study. A total of 475 undergraduate students in English preparatory classes voluntarily participated in the study. The findings showed that graded performance regarding English courses was significantly and positively predicted by both curiosity as a feeling of deprivation and curiosity as a feeling of interest. The findings also showed that graded performance regarding English courses was significantly, yet negatively predicted by anxiety and boredom.

\section{İngilizce hazırlık sınıflarındaki öğrencilerin başarı duyguları, bilgiye yönelik merakı ve ders başarısı}

Makale Bilgisi

DOI: $10.31704 /$ ijocis.2018.003

Makale Geçmişi:

Geliş $\quad 14$ Kasım 2017

Düzeltme 01 Mayıs 2018

Kabul 23 Mayıs 2018

Çevrimiçi 30 Haziran 2018

Anahtar Kelimeler:

Eğitim felsefesi,

Felsefi tercih,

Öğretmen adayları.
Öz

$\mathrm{Bu}$ araştırmanın amacı, İngilizce hazırlık sınıflarındaki üniversite öğrencilerinin İngilizce derslerine ilişkin başarı duyguları, bilgiye yönelik merakları ve ders başarıları arasındaki ilişkilerin incelenmesidir. Araştırmada açımlayıcı ilişkisel desen benimsenmiştir. Araştırmaya İngilizce hazırlık sınıflarındaki toplam 475 öğrenci gönüllü olarak katılmıştır. Araştırmanın bulguları, İngilizce ders başarısının hem yoksunluk hissi olarak merak hem de ilgi hissi olarak merak tarafından anlamlı düzeyde ve olumlu yönde yordandığını göstermiştir. Bulgular ayrıca, İngilizce ders başarısının kaygı ve can sıkıntısı tarafından anlamlı düzeyde, ancak olumsuz yönde yordandığını da göstermiştir.

\footnotetext{
*Author: alevelmali@gmail.com

**Author: eren_a@ibu.edu.tr
}

Orcid ID: https://orcid.org/0000-0002-6072-417X Orcid ID: https://orcid.org/0000-0001-8964-2082 


\section{Introduction}

With the increasing extent of communication among countries, which cannot be compared to the past, the requirement and importance of learning a foreign language is understood more in Turkey with each passing day (Koru \& Åkesson, 2011). However, in the English Proficiency Index, Turkey ranks 51st among 72 countries, and 25th among European countries where there are 26 countries in total (Education First-English Proficiency Index, 2016). In addition, according to the TOEFL (Test of English as a Foreign Language) exam results for the year 2012, Turkey ranks 116th together with Ethiopia, and Sudan in the list where there are 162 countries (Educational Testing Service, 2016).

These results indicate that teaching English as a foreign language is a major concern for Turkey. Therefore, it can be argued that it is important to focus on the individual differences variables that are related to the graded performance regarding English classes and learning English. Considerable research carried out in this context in the relevant literature. Findings from these studies showed that important individual difference variables such as achievement goals (Pintrich \& Schunk, 1996) perceived instrumentality (student perception on the value of a course serving the purpose/utility value of achieving their future-related goals) and future time perspective (Özçetin \& Eren, 2010) are significantly and positively associated with graded performance regarding English classes.

On the other hand, in the relevant literature, there appears to be less research on the relationships between affective variables and the graded performance (Lopez \& Aguilar, 2013). Moreover, attitude change ranks the first among the affective variables focused on these studies (Bağçeci, 2004; Saracaloğlu, 1995). In addition to the attitude variable, which is focused in these studies, it is also necessary to examine different affective variables. Indeed, the findings obtained in previous studies showed that the feelings of the students about their success in learning environments and their epistemic curiosity are closely related to both the quantity and the quality of the learning processes (Coleman, 2014; Litman \& Jimerson, 2004; Pekrun, 2006). However, there are no studies conducted on the relationship between emotional and epistemic curiosity and the success of English classes. In this context, the role of positive and/or negative emotions and curiosity, especially epistemic curiosity, in the learning process have long been acknowledged (Artino \& Stephens, 2007; Berlyne, 1960; Fowler, 1965). Therefore, it is important to examine the possible relationships of these variables together with graded performance regarding English classes. A detailed examination of the achievement emotions of students in their English language classes and their predictions of the course achievement of their epistemic curiosity can provide a comprehensive view for teachers/lecturers about individual difference variables that need to be taken into consideration in increasing success in English language classes. This may provide a robust theoretical framework for future curriculum development in terms of both planning the learning-teaching processes and in terms of the use/development of more effective teaching methods and techniques. It can be said that this statement is valid for every level of education. However, for universities (Higher Education Council, 2007), whose main objective is to raise individuals who can reach scientific knowledge about their fields, who can analyze this knowledge by interpreting it and who are able to create new knowledge, this can be predicted to be much more evident due to the fact that they constitute the main source of high quality workforce supply. For this reason, the aim of the research is to examine the relations between achievement emotions of university students studying in preparatory classes, epistemic curiosity and course achievements in English classes. In this respect, answers for three questions were sought within the context of the present study: (a) What are the levels of students' achievement emotions and epistemic curiosity levels in English classes? (b) Are there significant relationships between students' achievement emotions in English classes, epistemic curiosity, and course achievement? (c) Do students' epistemic curiosity and the achievement emotions in English classes significantly predict their graded performance regarding English classes?

\section{Conceptual Framework}

Epistemic curiosity: In the relevant literature, Curiosity has been studied through different concepts such as social curiosity (Renner, 2006), perceptual curiosity, and epistemic curiosity (Berlyne, 1954). Among them, epistemic curiosity, which can be briefly defined as "desire to know" (Berlyne, 1954, 187), is highly related to important pedagogical variables such as motivation, learning and academic achievement because of its characteristic of being an important driving force behind discovery-related behaviors (Litman, 2008, 2010). The approaches on epistemic curiosity can be summarized around two perspectives. Loewenstein (1994) defined the epistemic curiosity as the feeling of deprivation caused by the lack of information perceived by the 
individual between what is known and what is desired to be known; and claimed that as the lack of information perceived by the individual decreased, the deprivation feeling increased, and the desire for learning was exacerbated. The second is Curiosity as a Feeling of Interest as defined by Spielberger and Starr (1994). Spielberger and Starr (1994) noted that epistemic curiosity might be explained with the feeling of interest emerging when new and interesting stimuli appears for the individual at optimal level.

Conversely, Litman and Jimerson (2004) suggested that the epistemic curiosity might be explained by both the feeling of deprivation and the feeling of interest. While Curiosity as a Feeling of Interest, according to Litman and Jimerson (2004) and Litman $(2008,2010)$, corresponds to the pleasure of learning and discovering new things, Curiosity as a Feeling of Deprivation refers to the feeling of deprivation caused by the lack of information perceived by the individual between what is known and what is desired to be known, which is in line with the definition of Loewenstein (1994).

Curiosity as a Feeling of Interest arises through the interest that individuals feel when they are exposed to stimuli about an interesting topic that they know little or do not have any information about, and this, in turn, leads them to learn. Curiosity as a Feeling of Deprivation leads individuals to learn depending on the level of lack of knowledge they perceive between what they know and what they want to know (Litman, 2005, 2008, 2010). Litman (2005) suggested that the feelings of deprivation in the individual caused by the feeling of deprivation increased the need for learning more than the pleasure caused by interest. Indeed, the findings obtained through research in different contexts (e.g., pre-service teachers, high school students) support this prediction (Eren, 2009, 2011; Litman, 2008, 2010; Litman, Hutchins \& Russon, 2005). For example, Eren (2009) found that university students' Curiosity as a Feeling of Interest did not significantly relate to their mastery goals and performance-approach goals whereas their Curiosity as a Feeling of Deprivation did. However, it does not mean that Curiosity as a Feeling of Interest is less important than Curiosity as a Feeling of Deprivation. As a matter of fact, Curiosity as a Feeling of Interest and Curiosity as a Feeling of Deprivation are moderately and positively related to each other (Eren, 2011; Litman, 2008; Sorrentino \& Roney, 2000). Nevertheless, information seeking behaviors of individuals who are motivated by Curiosity as a Feeling of Interest are acted through the interest they perceive about information as a whole rather than the lack of information they feel. This is due to the fact that Curiosity as a Feeling of Deprivation and Curiosity as a Feeling of Interest are related to feelings with different valence (i.e., positive vs. negative emotions). Specifically, curiosity as a Feeling of Deprivation is accompanied by negative emotions like tension and uneasiness whereas Curiosity as a Feeling of Interest is accompanied by positive feelings like pleasure and enjoyment.

In the light of these explanations, it may be claimed that it is important to consider Curiosity as a Feeling of Interest together with Curiosity as a Feeling of Deprivation in order to examine epistemic curiosity in a comprehensive manner. Thus, in the current study, students' epistemic curiosity was examined through the mentioned two-factor structure (Litman \& Jimerson, 2004).

\section{Achievement emotions:}

Unlike other emotional theories/models, in the Control-Value Theory of Achievement Emotions originally developed by Pekrun (2006), emotions are defined as a series of psychological processes that contain interrelated affective, cognitive and motivational dimensions. More precisely, achievement emotions refer to the emotions that students feel about academic tasks (e.g., homework, exams, projects), processes (e.g., thinking, interpreting) and situations (e.g., obtaining a successful/unsuccessful result from a test) (Pekrun, 2006; Pekrun et al., 2002). In this sense, the concept of control refers to the control perceived about tasks, processes, and situations (e.g., the degree of autonomy perceived by a student about the selection of the assignment topic), and the concept of value refers to the cognitive appraisals assigned to the results of these processes and situations (e.g., the degree of importance perceived by a student to complete the assignment successfully) (Pekrun, 2006). The interaction between the perceived control and value are the determinants of both the focus of emotions felt by the students (result-oriented/process-oriented emotions) and the valence (positive/negative emotions) as well as the tendency to act accordingly (activating/deactivating emotions).

The Control-Value Theory of Achievement Emotions allows a multidimensional classification of achievementrelated emotions. In this respect, a student's enjoyment with the learning process during any class can be described as an activating emotion because it is positive, process-oriented and motivates the student to participate in the process. However, the relaxation felt by the student after completing and submitting a homework assignment can be defined as a positive, yet deactivating emotion because it no longer requires the student to engage with another task regarding this homework. Similarly, the anxiety felt by a student during an exam can be described as an activating emotion because the anxiety felt by a student on the test is negative, process-oriented and motivates the student to do something to decrease the level of his/her anxiety. The 
boredom felt by the student during classes is negative and process-oriented, yet deactivating emotion because it leads students to detach a task at hand behaviorally or mentally.

It is also important to highlight that achievement emotions are felt as a result of the cognitive appraisals (Pekrun, 2006). For example, if completing an assignment on mathematics is considered important, and if the perceived control of the homework is high, completing the homework may lead to positive emotions (e.g., pride). This may affect the motivation and achievement for the following assignment. Indeed, achievement emotions are significantly related to students' self-regulation skills, motivations for learning, and academic achievement according to their valence, focal points and the activation characteristics (Artino, Holmboe \& Durning, 2012; Daniels et al., 2009; Frenzel, Pekrun \& Goetz, 2007; Pekrun, Frenzel, Goetz \& Perry 2007). Both because of this, and also because it is the unique theory allowing to examine students' achievement emotions in educational settings comprehensively, students' achievement emotions regarding English classes were examined based on the Control-Value Theory of Achievement Emotions framework in the present study.

\section{Method}

The survey method was used in the study. The design of the study was exploratory correlational design. This design enables the examination of the relationships between the variables of a study in an inductive manner (Creswell, 2009; Fraenkel \& Wallen, 2006), and is used in situations where there is little or no evidence regarding the relationships between the research variables.

\section{The Universe and the Sample of the Study}

The universe of the study consisted of a total of 3,200 preparatory class students attending Hacettepe University and Abant Izzet Baysal University in the 2014-2015 academic year. The sample of the study consisted of 475 randomly selected undergraduate students (female $=200$; male $=275$ ) from the universe. Of them, 234 were enrolled in Hacettepe University and 241 were enrolled in Abant Izzet Baysal University. Furthermore, 204 students were Anatolian High School graduates, 176 students were General High School graduates, 33 were Science High School graduates, 44 were Vocational High School graduates, and 18 were Teacher Training High School graduates. The average age of the students was $19.38(S D=1.00)$.

\section{Research Instruments}

The Epistemic Curiosity Scale: The Epistemic Curiosity Scale, originally developed by Litman (2008) and adapted into Turkish by Eren (2009, 2011), was used to assess students' epistemic curiosity. The scale consists of two factors: Curiosity as a Feeling of Interest (e.g., I find it fascinating to learn new information) and Curiosity as a Feeling of Deprivation (e.g., I work like a fiend at problems that I feel must be solved), each of which contains five items. The students were asked to respond to the items in the scale with their English classes in mind. Students responded to the items of the scale on a four-point Likert-type scale ranging from 1 (almost never) to 4 (almost always).

The Achievement Emotions Questionnaire: In order to assess students' achievement emotions, the Achievement Emotions Questionnaire was used. The questionnaire was originally developed by Pekrun, Goetz and Perry (2005, Pekrun, Frenzel, Goetz \& Perry, 2007) and adapted into Turkish by the author of the present study by using the Committee Approach (Dörnyei, 2010). Originally, the items were written for mathematics classes. However, due to the scope of the present study, the items were slightly modified and the term 'mathematics class/this class' was replaced by the term 'English class'. The questionnaire consists of three parts: class-related, learning-related and test-related. Because the current study focused on the English classes, class-related section of the Achievement Emotions Questionnaire was used. This part consists of 19 items that formed six factors: enjoyment (Four items: e.g., I look forward to my English class); anxiety (Four items: e.g., When thinking about my English class, I get nervous), boredom (Three items: e.g., I think the English class is boring); anger (Four items: e.g., I get irritated by my English class.); shame (Two items: e.g., When I say something in my English class, I feel like embarrassing myself) and pride (Two items: e.g., I think I can be proud of my knowledge in English). The students responded on the items in the scale based on the response options ranged from 1 (I definitely disagree) to 5 (I definitely agree).

Two separate Confirmatory Factor Analyses (CFA) were conducted to examine whether the factor structures of the research instruments would be confirmed in the current sample. The results showed that the factor structures of both the Achievement Emotions Questionnaire (X2 (137) = 361.09; CFI = .99; NNFI = .98; RMSEA $=.06 ;$ SRMR $=.03)$ and the Epistemic Curiosity Scale had good fit to the current data $(x 2(34)=87.72 ; \mathrm{CFI}$ $=.97 ; \mathrm{NNFI}=.96 ; \mathrm{RMSEA}=.06 ;$ SRMR $=.04)($ Kline, 2011). In addition, Cronbach's coefficients alphas for enjoyment $(\alpha=.87)$, anxiety $(\alpha=.89)$, boredom $(\alpha=.89)$, irritability $(\alpha=.80)$, shame $(\alpha=.65)$ subscales as well 
as the alphas for the Curiosity as a Feeling of Interest $(\alpha=.68)$ and Curiosity as a Feeling of Deprivation $(\alpha=.81)$ subscales were adequate.

Graded performance regarding English classes: For the graded performance regarding English classes, the average scores of the students received from the exams taken in English classes throughout two semesters and the average scores received by the students from the proficiency test which was conducted at the end of the academic year were used.

\section{Procedure and the Data Analysis}

After the required permissions were received, the data were collected by the first author of the present study at a time that was appropriate for the lecturers of the English classes. The Achievement Emotions Questionnaire and the Epistemic Curiosity Scale were given to the students with instructions that included the purpose of the study and explanations on how to respond on the items of the scales. In the administration process, any questions from students were answered and additional explanations were made when necessary. The administration process lasted approximately 20 minutes. A series of one-sample t tests were conducted to answer the first research question. A zero-order (Pearson) correlation analysis was conducted to answer the second research question. In order to answer the third research question, a multiple regression analysis was conducted in which the aspects of epistemic curiosity and the achievement emotions (enjoyment, anxiety, boredom, anger, shame, and pride) were determined as independent variables, whereas the graded performance regarding English classes was determined as the dependent variable (Field, 2009). In the regression analysis, although they were not the focus of this study, the demographic variables (i.e., age, gender, graduated high school type, and the university) were also included because they could significantly affect the dependent variables. In order to investigate the findings obtained through the regression analysis with a more reliable approach, a structural model was created in which the variables found to be significantly related to the graded performance regarding English courses were determined as the independent variables, whereas the graded performance regarding English classes was determined as the dependent variable. This model was examined through the Structural Equation Modeling (SEM) analysis.

\section{The Results of One-Sample $t$ Tests}

\section{Findings}

As seen in Table 1, the $t$ values that were computed in relation to the epistemic curiosity and achievement emotions did not significantly differ from the test values which were computed based on the midpoints of the scales (e.g., the midpoint for anxiety factor was computed as ( $4 \times 3) 12$ ) (all $p$ values $>.05$ ). This means that the levels of students' achievement emotions regarding English classes and the epistemic curiosity are moderate.

Table 1.

The Results of the One-sample t Tests.

\begin{tabular}{|c|c|c|c|c|c|}
\hline Variable & Test Value & $\overline{\mathbf{x}}$ & SD & $t$ & $p$ \\
\hline Curiosity as a Feeling of Interest & 12.5 & 14.76 & 2.44 & .02 & .99 \\
\hline Curiosity as a Feeling of Deprivation & 12.5 & 14.15 & 3.47 & .03 & .97 \\
\hline Enjoyment & 12 & 11.08 & 3.35 & .01 & .99 \\
\hline Anxiety & 12 & 11.70 & 3.88 & .03 & .98 \\
\hline Boredom & 9 & 10.04 & 3.99 & .02 & .98 \\
\hline Anger & 12 & 15.82 & 3.17 & .01 & .99 \\
\hline Shame & 6 & 6.26 & 2.47 & .01 & .99 \\
\hline Pride & 6 & 6.46 & 2.46 & .01 & .99 \\
\hline
\end{tabular}

\section{The Results of Correlation Analysis}

When the sample is relatively large, which is the case in the present study, the magnitude of the correlation coefficients should be taken into account in interpreting the relationships between the research variables rather than the significance levels because of the possibility that even small correlation coefficients may be statistically significant in large samples (Field, 2009). As seen in Table 2, both Curiosity as a Feeling of Interest and Curiosity as a Feeling of Deprivation were positively and moderately related to graded performance regarding English classes. Achievement emotions were moderately and selectively related to graded performance regarding English classes. Specifically, enjoyment and pride were positively and moderately associated with graded performance, whereas, with coefficients ranging from -.42 to -.57, anxiety, boredom, 
anger and shame were negatively correlated with graded performance. Achievement emotions, on the other hand, were selectively and moderately related to Curiosity as a Feeling of Interest with correlation coefficients ranged in magnitude from -.46 to .46 , while they were selectively, yet somewhat weakly related to Curiosity as a Feeling of Deprivation with correlation coefficients ranged in magnitude from -.32 to .33.

Table 2.

Correlation Analysis Results.

\begin{tabular}{|c|c|c|c|c|c|c|c|c|c|}
\hline Variable & 1 & 2 & 3 & 4 & 5 & 6 & 7 & 8 & 9 \\
\hline 1. Graded Performance & - & & & & & & & & \\
\hline 2. Curiosity as a Feeling of Interest & .50 & - & & & & & & & \\
\hline 3. Curiosity as a Feeling of Deprivation & .46 & .30 & - & & & & & & \\
\hline 4. Enjoyment & .48 & .46 & .33 & - & & & & & \\
\hline 5. Anxiety & -.54 & -.31 & -.31 & -.52 & - & & & & \\
\hline 6. Boredom & -.57 & -.46 & -.30 & -.57 & .58 & - & & & \\
\hline 7. Anger & -.56 & -.43 & -.32 & -.56 & .61 & .78 & - & & \\
\hline 8. Shame & -.42 & -.43 & -.20 & -.48 & .43 & .71 & .63 & - & \\
\hline 9. Pride & .54 & .46 & .29 & .64 & -.54 & -.68 & -.68 & .52 & - \\
\hline
\end{tabular}

Note: All correlation coefficients are significant at $p<.01$ level of significance.

\section{The Results of Multiple Regression Analysis}

As seen in Table 3, both Curiosity as a Feeling of Interest and Curiosity as a Feeling of Deprivation significantly and positively predicted graded performance regarding English classes. Among the achievement emotions, only anxiety and boredom significantly, yet negatively predicted graded performance. Notably, these results are free from the effects of the university where the participants enrolled, high school types the participants graduated from, and the gender and age variables (all $p$ values $>.05$ ). In fact, the demographic variables explained only $1 \%$ of the total variance in graded performance whereas the epistemic curiosity and achievement emotions explained $50 \%$ of the total variance.

Table 3.

Multiple Regression Analysis Results.

\begin{tabular}{lrrrrrr}
\hline Variables & B & S.E. & $\boldsymbol{\beta}$ & $\boldsymbol{t}$ & $\boldsymbol{p}$ & VIF \\
\hline University & .08 & .85 & .00 & .09 & .92 & 1.10 \\
Gender & .70 & .85 & .03 & .82 & .41 & 1.07 \\
Age & .21 & .43 & .02 & .49 & .62 & 1.09 \\
High School Type & .01 & .38 & .00 & .02 & .98 & 1.05 \\
Curiosity as a Feeling of Interest & 1.17 & .20 & .23 & $5.78^{* * *}$ & .00 & 1.48 \\
Curiosity as a Feeling of Deprivation & .81 & .13 & .22 & $6.25 * * *$ & .00 & 1.21 \\
Enjoyment & .02 & .17 & .01 & .13 & .89 & 2.02 \\
Anxiety & -.71 & .14 & -.22 & $-5.00^{* * *}$ & .00 & 1.80 \\
Boredom & -.50 & .19 & -.16 & $-2.59 *$ & .01 & 3.62 \\
Anger & -.34 & .23 & -.09 & -1.49 & .13 & 3.15 \\
Shame & .21 & .24 & .04 & .85 & .39 & 2.19 \\
Pride & .51 & .26 & .10 & 1.95 & .05 & 2.48 \\
\hline
\end{tabular}

${ }^{* * *} p<.001 ;{ }^{*} p<.05 ;$ Note: S.E.= Standard Error; $\beta$ = Standardized Beta Coefficient; VIF = Variance Inflation Factor; VIF values are smaller than 5 (Field, 2009).

\section{The results of Structural Equation Modeling Analysis}

A structural model was created based on the correlational patterns that appeared as a result of the multiple regression analysis (Figure 1); and this model was investigated through SEM analysis. As a result of the SEM analysis, it was observed that the structural model had good fit to the current data $\left(\chi^{2}(126)=313.70 ; C F I=.98\right.$; $\mathrm{NNFI}=.97$; RMSEA $=.06$; SRMR = .04). Similar to the results of the regression analysis, the results of the SEM analysis showed that the Curiosity as a Feeling of Interest, Curiosity as a Feeling of Deprivation, boredom, and anxiety significantly and selectively predicted graded performance regarding English classes. 


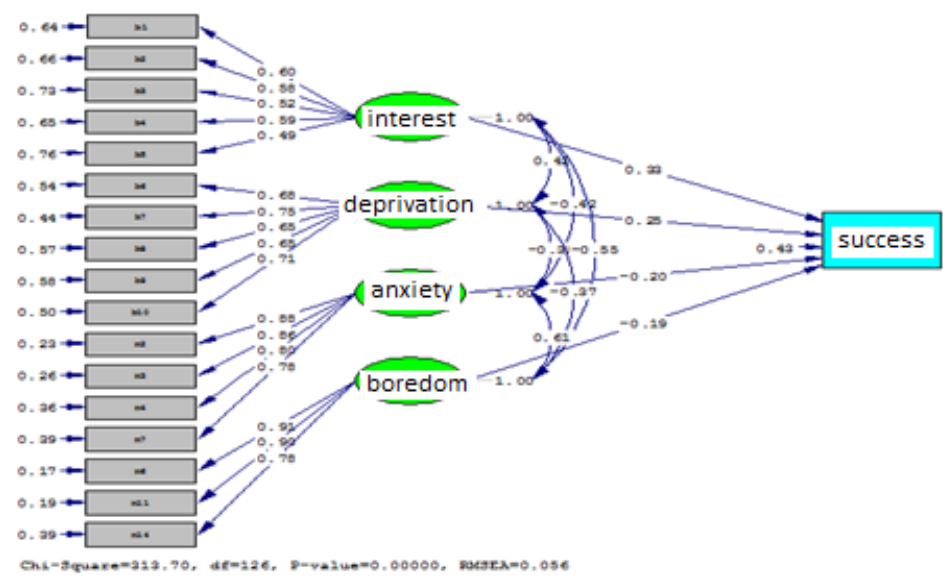

Figure 1. The Structural Model of the Predictors of Graded Performance regarding English Class.

\section{Discussion, Conclusion and Suggestions}

The results of the one-sample t tests showed that students in the English preparatory classes had a positive and negative sense of accomplishment regarding English classes and a moderate level of interest in knowledge. This finding of the study can be considered as a sign showing that the students feel many positive and negative achievement emotions in English classes. Given the fact that English classes, similar to other classes, are learning environments that provide stimuli that can lead students to feel both positive (e.g., enjoyment, pride) and negative emotions (e.g., boredom, anxiety) (e.g., the anxiety of an approaching English exam, a student is happy with a correctly answered question, the monotony of the subject causing annoyance), it can be said that this finding is not surprising. Indeed, it can be expected that positive and/or negative achievement emotions can be felt as a result of the feedback (positive/negative achievement-related feedback) of various communicative activities (e.g., verbal, written) in English classes which are the learning environments where communication activities are used in an intensive manner. This finding is in line with the findings reported by Goetz, Frenzel, Hall and Pekrun (2008) demonstrating that students often felt achievement emotions in academic settings. The results obtained via the one-sample t tests also showed that students experienced both Curiosity as a Feeling of Deprivation and Curiosity as a Feeling of Interest in their English classes. This finding of the present study gains an understandable appearance when it is taken into consideration that the communication processes that take place during classes (e.g., providing feedback) can stimulate not only emotions, but also the epistemic curiosity (Kang et al., 2009).

Another noteworthy finding is that the epistemic curiosity and achievement emotions were felt at a moderate level by the students in English classes rather than at a strong or weak level. This finding of the study might be related to the fact that the activities/assignments (e.g., examinations, tasks) in English classes are not perceived as either difficult or easy by the students. For example, in his study where the role of graphic organizers in vocabulary teaching were examined, ilter (2016) reported that positive achievement emotions were felt more strongly in the experimental group that were taught through graphic organizers than in the control group.

Although there are no studies conducted on epistemic curiosity within this context, it could be expected that using appropriate teaching techniques (e.g., communication games) together with effective materials such as three-dimensional visuals may arouse Curiosity as a Feeling of Interest in students. In addition, depending on the deprivation feeling that will be caused by the missing information perceived between the old and new information on the subject matter, it may also be expected that this and similar materials arouse Curiosity as a Feeling of Deprivation (at least in moderately) in English classes. The results of the correlation analysis revealed that the achievement emotions and graded performance regarding English classes were significantly and selectively associated with each other. The results also showed that Curiosity as a Feeling of Interest and Curiosity as a Feeling of Deprivation were significantly and positively associated with graded performance.

Given that the epistemic curiosity and emotions are reciprocally associated with perceived ability, self-efficacy, academic achievement and academic self (Putwain and Deveney, 2009) and also given the significant roles of emotions in explaining student behavior in educational settings and academic achievement (Berlyne, 1954; Litman, 2008, 2010; Loewenstein, 1994; Skinner, Furrer, Marchand \& Kindermann, 2008), it may be understood 
why these variables were significantly related to the graded performance. In fact, the results obtained through correlation analysis were in line with the findings demonstrating that epistemic curiosity was positively and strongly related to cognitive activity levels (Tamdogon, 2006), learning (Day, 1982), and academic achievement and in accordance with the Pekrun's (2006) findings showing that negative emotions (e.g., anxiety) were negatively associated with academic achievement, whereas positive emotions (e.g., pride) were positively related to academic achievement.

On the other hand, the results of correlation analysis showed that the relationships between achievement emotions and Curiosity as a Feeling of Interest were stronger than that of their associations with Curiosity as a Feeling of Deprivation. One possible reason for this is that Curiosity as a Feeling of Interest has a more positive affective content than Curiosity as a Feeling of Deprivation (Litman, 2008). Another possible reason is that a positive feeling like interest increases the motivations of students to learn English more when compared to a negative feeling like deprivation. This explanation is also consistent with the fact that interest is a strong source of motivation (Hidi, 2006). In turn, this may lead students to feel more positive emotions, but less negative emotions, during English classes. However, because the current research is carried out based on the correlational design by using a cross-sectional data, these explanations are at least partly controversial, albeit reasonable. Thus, experimental studies are needed to infer causality regarding the current topic.

Results of the multiple regression analysis and SEM analysis showed that the boredom and anxiety significantly predicted graded performance regarding English classes. It is noteworthy to mention that negative emotions such as boredom and anxiety, but not positive achievement emotions such as enjoyment, significantly predicted the graded performance. This can be because only two positive achievement emotions (i.e., enjoyment and pride) and four negative achievement emotions (i.e., shame, boredom, anger, and anxiety) were considered in the study. Indeed, this may cause to suppress the effects of positive achievement emotions on graded performance regarding English classes by the effects of negative achievement emotions. Notably, it is intriguing to observe that demographic variables accounted for only $1 \%$ of the total variance related to the graded performance and that the Anatolian High Schools were described as one of the high schools that the participants of this study were graduated from. This is because the hours of foreign language lessons in Anatolian high schools are more than that of those in other types of high schools. This result can be interpreted as graded performance regarding English classes depends on the quality rather than the quantity of the class hours. However, because the present study did not focus on the quality of English language classes, this interpretation is quite controversial, albeit reasonable. It is obvious that this interpretation requires further investigations.

In relation to the results showing that the graded performance regarding English classes was significantly predicted by boredom and anxiety, but not by shame and anger can be explained by the fact that boredom is a negative and deactivating emotion (that lead students to wander away from the learning environment in a behavioral/mental sense). The mentioned characteristic of boredom makes it difficult to detect it in educational settings such as classrooms (Pekrun, 2006) and increases the likelihood of boredom in affecting achievement negatively unlike activating negative emotions such as anger and shame (Bridgeland, Dilulio \& Morison, 2006). This explanation is consistent with the results of previous research which showed that boredom was significantly and negatively correlated with course achievement (Pekrun, Goetz, Daniels, Stupnisky \& Perry, 2010). In contrast to boredom, anxiety is an activating emotion. However, the likelihood of anxiety in causing disruptive behaviors might be lower than other negative and activating achievement emotions, such as anger and shame, because it is an expectation-oriented emotion. Thus, anxiety, similar to boredom, may cause reactions that are difficult to detect in educational settings. A student's engagement with other topics rather than preparing for an exam, dealing with other topics, and moving away from the lesson by daydreaming in order to reduce the anxiety created by her/his expectation of failing a test that will be taken in the near future may be given as examples of such reactions. In turn, this may increase the negative effect of anxiety on graded performance regarding English classes, when compared to other negative emotions. These explanations are also consistent with the results of previous studies in which the relationship between anxiety and graded performance regarding foreign language courses were examined (Batumlu \& Erden, 2007; Salim, 2004; Worde, 2003).

The results of the regression analysis and SEM analysis also showed that Curiosity as a Feeling of Interest and Curiosity as a Feeling of Deprivation significantly predicted students' graded performance regarding English classes. Although the types of epistemic curiosity are characterized by different feelings, they consist of a common content that converge on the axis of new knowledge acquisition (Litman, 2008). Moreover, there are findings in the relevant literature showing that both curiosity factors are positively and strongly related to 
academic achievement/course achievement (Eren \& Coşkun, 2016; Serin, 2010). Therefore, it can be expected that the mentioned curiosity types may significantly and positively predict graded performance regarding English classes.

Based on the abovementioned findings of the present study, three important conclusions can be derived. First, English lessons in preparatory classes are not the environments that are deprived of epistemic curiosity and positive and negative achievement emotions. Second, achievement emotions and epistemic curiosity are significantly and selectively related to graded performance regarding English classes. Third, and more importantly, negative achievement emotions, particularly boredom and anxiety, negatively predict graded performance regarding English classes whereas Curiosity as a Feeling of Interest and Curiosity as a Feeling of Deprivation positively predict graded performance regarding English classes.

Therefore, lecturers of the English preparatory classes should consider that their students feel positive emotions such as enjoyment and pride together with negative feelings such as anxiety, boredom, shame, and anger during the classes and that, among them, particularly boredom and anxiety are negatively related to graded performance regarding English classes. In this respect, it can be said that the attempts of lecturers to reduce anxiety (e.g., by creating a positive and supportive classroom climate) and boredom (e.g., by informing students about cognitive approach strategies that are effective in reducing boredom (Nett, Goetz \& Daniels, 2010) during English classes will contribute to increase graded performance regarding English classes. However, lecturers can increase their students' graded performance regarding English classes not only by reducing the level of feeling of negative emotions such as anxiety and boredom but also through activities that can stimulate epistemic curiosity. These activities would be visual (e.g., interesting, static and/or dynamic visuals) and auditory (e.g., music) stimuli (Berho \& Defferding, 2005) as well as imaginary activities that are designed to increase situational interest (Doğru \& Eren, 2016). Although the aforementioned results of the study may enable to make these and similar educational suggestions, the results should be cautiously interpreted in future studies because the current study only included students from English preparatory classes of two different universities, the graded performance regarding English classes was assessed based on the results of exams prepared by the lecturers, and it was conducted based on a relatively small sample. Therefore, findings that will be obtained from future studies that are conducted based on a large number of universities and larger samples of students, and assessed graded performance through standardized achievement tests, may contribute to the investigation of the generalizability of the present results. Additionally, the results of future empirical studies in which epistemic curiosity or achievement emotions are manipulated may enlarge the correlational framework obtained in the present study because they facilitate to make causal inferences.

\section{Acknowledgement}

This study is a part of first author's Master's dissertation, supervised by the second author. A part of this study was presented at $26^{\text {th }}$ International Conference on Educational Sciences (20-23 April 2017, Antalya, Turkey). 


\section{TÜRKÇE SÜRÜM}

\section{Giriş}

Ülkeler arasındaki iletişimin geçmişle kıyaslanamayacak ölçüde artmasıyla, Türkiye'de yabancı dil öğrenmenin gereği ve önemi gün geçtikçe daha fazla anlaşılmaktadır (Koru \& Åkesson, 2011). Buna rağmen, İngilizce Yeterlilik Endeksi sıralamasında Türkiye 72 ülke içerisinde 51. sırada, 26 Avrupa ülkesinin yer aldığı sıralamada ise 25. sırada yer almaktadır (Education First-English Proficiency Index, 2016). Ayrıca, 2012 yılında gerçekleştirilen TOEFL (Test of English as a Foreign Language) sınav sonuçlarına göre, 162 ülkenin yer aldığı listede Türkiye, Habeşistan ve Sudan ile birlikte 116. sırada yer almaktadır (Educational Testing Service, 2016).

Bu sonuçlar, bir yabancı dil olarak İngilizce öğretiminin Türkiye açısından önemli bir problem durumu olduğuna işaret etmektedir. Dolayısıyla, İngilizce öğrenmeyle ve İngilizce ders başarısıyla ilişkilenen bireysel farklııı değişkenlerine odaklanmanın önemli olduğu ifade edilebilir. Konuyla ilgili alanyazında bu bağlamda gerçekleştirilen dikkate değer sayıda araştırma bulunmaktadır. Bu araştırmalardan elde edilen bulgular, başarı amaçları (Pintrich \& Schunk, 1996), algılanan araçsalık (öğrencilerin, bir dersin kendi amaçlarına hizmet etme derecesine/fayda değerine ilişkin algıları) ve gelecek zaman perspektifi (Özçetin \& Eren, 2010) gibi önemli bireysel farkılık değişkenlerinin, İngilizce ders başarısıyla anlamlı düzeyde ve olumlu yönde ilişkilendiğini göstermiştir.

Diğer taraftan, konuyla ilgili alanyazında duyuşsal değişkenlerin İngilizce ders başarısıyla ilişkilerinin araştırıldığı oldukça az sayıda araştırma bulunmaktadır (Lopez \& Aguilar, 2013). Üstelik bu araştırmalarda odaklanılan duyuşsal değişkenlerin başında tutum değişkeni gelmektedir (Bağçeci, 2004; Saracaloğlu, 1995). Tutumun yanı sıra farklı duyuşsal değişkenlerin de incelenmesi gereklidir. Nitekim araştırmalar aracılığıyla elde edilen bulgular, öğrencilerin eğitim ortamlarında hissettikleri başarıyla ilgili duyguların ve bilgiye yönelik meraklarının öğrenme sürecinin hem niceliğiyle hem de niteliğiyle yakından ilişkili olduğunu göstermiştir (Coleman, 2014; Litman \& Jimerson, 2004; Pekrun, 2006). Ancak, alanyazında duygular ve bilgiye yönelik merakın, İngilizce ders başarısıyla ilişkilerinin incelendiği bir çalışmaya rastlanmamıştır. Oysa olumlu ve/veya olumsuz duyguların ve merakın, özellikle de bilgiye yönelik merakın, öğrenme sürecindeki rolleri uzun zamandan bu yana bilinmektedir (Artino \& Stephens, 2007; Berlyne, 1960; Fowler, 1965). Dolayısıyla, söz konusu değişkenlerin İngilizce ders başarısıyla olası ilişkilerinin sorgulanması önemlidir. Öğrencilerin İngilizce derslerinde hissettikleri başarı duygularıyla bilgiye yönelik meraklarının ders başarısını yordama durumlarının ayrıntılı olarak incelenmesi; İngilizce ders başarısının artırılmasında dikkate alınması gereken bireysel farklılık değişkenleriyle ilgili olarak, öğretmenlere/öğretim elemanlarına kapsamlı bir bakış açısı sağlayabilir. Bu da sırasıyla, ileride gerçekleştirilecek program geliştirme çalışmalarına, hem öğrenme-öğretme süreçlerinin planlanması açısından hem de daha etkili öğretim yöntem ve tekniklerin kullanılması/geliştirilmesi açısından sağlam bir kuramsal çerçeve sağlayabilir. İfade edilen önemin, eğitimin her kademesi için geçerli olduğu söylenebilir. Ancak, temel hedefi, alanıyla ilgili bilimsel bilgilere ulaşabilen, bunları yorumlayarak analiz edebilen ve yeni bilgi(ler) oluşturabilen bireyler yetiştirmek olan üniversiteler (Yükseköğretim Kurulu, 2007) açısından bu önemin, niteliği yüksek iş gücü arzının başlıca kaynağını oluşturmaları nedeniyle çok daha belirgin olduğu öngörülebilir. Bu nedenle, araştırmanın amacı, hazırlık sınıflarında öğrenim gören üniversite öğrencilerinin İngilizce derslerine ilişkin başarı duyguları, bilgiye yönelik merakları ve ders başarıları arasındaki ilişkilerin incelenmesi olarak belirlenmiştir. Bu amaç doğrultusunda üç soruya yanıt aranmıştır: (a) Öğrencilerin İngilizce dersine ilişkin başarı duyguları ve bilgiye yönelik merak düzeyleri nedir? (b) Öğrencilerin İngilizce dersine ilişkin başarı duyguları, bilgiye yönelik merakları ve ders başarıları arasında anlamlı ilişkiler var mıdır? (c) Öğrencilerin İngilizce dersine ilişkin bilgi kaynaklı merakları ve İngilizce dersine ilişkin başarı duyguları İngilizce ders başarılarını anlamlı düzeyde yordamakta mıdır?

\section{Kavramsal Çerçeve}

Bilgiye Yönelik Merak: Konuyla ilgili alanyazında merak, sosyal merak (Renner, 2006), algısal merak ve bilgiye yönelik merak (Berlyne, 1954) gibi farklı kavramlar aracılığıyla incelenmektedir. Bunlar arasında, kısaca "bilme arzusu" (Berlyne, 1954, 187) olarak tanımlanabilen bilgiye yönelik merak, keşif davranışlarının ardında yatan önemli bir itici güç olma özelliği nedeniyle motivasyon, öğrenme ve akademik başarı gibi eğitim bilimsel anlamda önemli değişkenlerle yakından ilişkilidir (Litman, 2008, 2010). Bilgiye yönelik meraka ilişkin yaklaşımlar iki bakış açısı etrafında özetlenebilir. Birincisi, Loewenstein (1994) tarafından tanımlanan yoksunluk hissi olarak meraktır. Loewenstein (1994) bilgiye yönelik merakı, bilinenle bilinmek istenen arasında birey tarafından 
algılanan bilgi eksikliğinin neden olduğu yoksunluk hissi olarak tanımlamış, bireyin algıladığı bilgi eksikliği azaldıkça hissedilen yoksunluk duygusunun arttığını ve öğrenme arzusunun şiddetlendiğini öne sürmüştür. İkincisi ise, Spielberger ve Starr (1994) tarafından tanımlanan ilgi hissi olarak meraktır. Spielberger ve Starr (1994) bilgiye yönelik merakın, yeni ve ilgi çekici uyaranların bireyi optimal düzeyde uyarmasıyla ortaya çıkan ilgi hissiyle açıklanabileceğini ifade etmişlerdir.

Diğer taraftan, Litman ve Jimerson (2004) bilgiye yönelik merakın hem yoksunluk hissiyle hem de ilgi hissiyle açıklanabileceğini öne sürmüşlerdir. Litman ve Jimerson (2004) ile Litman, 2008, 2010)'a göre ilgi hissi olarak merak (curiosity as a feeling of interest) yeni şeyler keşfetmekten ve öğrenmekten zevk almaya karşılık gelirken, yoksunluk hissi olarak merak (curiosity as a feeling of deprivation), Loewenstein'in (1994) tanımıyla paralel biçimde, bilinenle bilinmek istenen arasında birey tarafından algılanan bilgi eksikliğinden kaynaklanan yoksunluk hissini ifade etmektedir.

ilgi hissi olarak merak, bireylerin hakkında çok az şey bildikleri ya da bilgilerinin olmadığı ilgi çekici bir konuyla ilgili uyaranlara maruz kaldıklarında hissettikleri ilgi aracılığıyla ortaya çıkmakta ve bu da bireyleri öğrenmeye yöneltmektedir. Yoksunluk hissi olarak merak ise, bireylerin herhangi bir konuda ne bildikleri ile neyi/neleri bilmeyi arzuladıkları arasında algıladıkları bilgi eksikliğinin düzeyine bağlı olarak bireyleri öğrenmeye yöneltmektedir (Litman, 2005, 2008, 2010). Litman (2005), yoksunluk hissinin bireylerde oluşturduğu gerginliğin ve huzursuzluğun öğrenme ihtiyacını, ilginin oluşturduğu haz duygusuna kıyasla daha fazla artıracağını öne sürmüştür. Nitekim farklı bağlamlarda gerçekleştirilen (öğretmen adayları, lise öğrencileri) araştırmalar aracılığıyla elde edilen bulgular, bu öngörüyü destekler niteliktedir (Eren, 2009, 2011; Litman, 2008, 2010; Litman, Hutchins \& Russon, 2005). Örneğin, Eren (2009) üniversite öğrencilerinin ilgi hissi olarak meraklarının değil, yoksunluk hissi olarak meraklarının öğrenme amaçları ve performansa yaklaşma amaçlarıyla anlamlı düzeyde ilişkilendiğini saptamıştır. Ancak bu, ilgi hissi olarak merakın yoksunluk hissi olarak meraktan daha az önemli olduğu anlamına gelmemelidir. Nitekim ilgi hissi olarak merak ve yoksunluk hissi olarak merak türleri birbiriyle orta düzeyde ve olumlu yönde ilişkilenmektedir (Eren, 2011; Litman, 2008; Sorrentino \& Roney, 2000). Diğer taraftan, ilgi hissi olarak merak aracılığıyla motive olan bireylerin bilgiye ulaşma davranışları, hissettikleri bilgi eksikliğinden çok, bilgi bütününe yönelik olarak hissettikleri ilgi aracılığıyla harekete geçirilmektedir. Bu durum, yoksunluk hissi olarak merak ve ilgi hissi olarak merakın farklı bağ-değerine (valence - duyguların olumlu ya da olumsuz olma özelliği) sahip duygularla ilişkili olmasından kaynaklanmaktadır. Nitekim yoksunluk hissi olarak meraka gerginlik ve huzursuzluk gibi olumsuz duygular, ilgi hissi olarak meraka ise hoşlanma ve keyif alma gibi olumlu duygular eşlik etmektedir.

Bu açıklamalar ışığında, ilgi hissi olarak merak ve yoksunluk hissi olarak merakın bir arada ele alınmasının, bilgiye yönelik merakın kapsamlı biçimde incelenmesi açısından önemli olduğu ifade edilebilir. Bu nedenle, araştırmada, öğrencilerin bilgiye yönelik merakı söz konusu iki faktörlü yapı aracılığıyla incelenmiştir (Litman \& Jimerson, 2004).

Başarı duyguları: Diğer duygu teorilerinden/modellerinden farklı olarak, Pekrun (2006) tarafından geliştirilen başarı duygularının kontrol-değer teorisinde duygular, birbirleriyle ilişkili duyuşsal, bilişsel ve motivasyonla ilgili boyutları olan bir dizi psikolojik süreç olarak tanımlanmaktadır. Daha açık bir ifadeyle, başarı duyguları okullar gibi başarı odağının belirgin olduğu ortamlarda, öğrencilerin akademik görevlerle (ödevler, projeler vb.), süreçlerle (düşünme, yorumlama vb.) ve durumlarla (bir sınavdan başarılı/başarısız sonuç elde etme) ilgili olarak hissettikleri duyguları ifade etmektedir (Pekrun, 2006; Pekrun et al., 2002). Kontrol kavramı söz konusu görevler, süreçler ve durumlara ilişkin olarak algılanan kontrole (örneğin, bir öğrencinin ödev konusunun seçiminde ne oranda söz sahibi olduğu), değer kavramı ise bunların sonucuna atfedilen değere (örneğin, bir öğrencinin ödevini başarıyla tamamlamasının kendisi için ifade ettiği önem) yönelik bilişsel değerlendirmeleri ifade etmektedir (Pekrun, 2006). Algılanan kontrol ve değer arasındaki etkileşim, öğrenciler tarafından hissedilen duyguların hem odağının (sonuç odaklı/süreç odaklı duygular) ve bağ-değerinin (olumlu/olumsuz duygular), hem de davranışta bulunma eğilimine yol açma durumunun (aktifleştirici/pasifleştirici duygular) belirleyicisi konumundadır.

Başarı duygularının kontrol-değer teorisi, başarı duygularının çok boyutlu bir sınıflamasına olanak sağlamaktadır. Buna göre, bir öğrencinin herhangi bir ders esnasında öğrenmeden aldığı keyif olumlu, süreç odaklı ve öğrenciyi sürece katılmaya motive etmesi nedeniyle aktifleştirici bir duygu olarak ifade edilebilir. Ancak, öğrencinin bir ödevi tamamlayıp öğretmenine teslim ettikten sonra hissettiği rahatlama, ödevle ilgili başka bir göreve odaklanmayı gerektirmemesi nedeniyle olumlu, ancak pasifleştirici bir duygu olarak tanımlanabilir. Benzer biçimde, bir öğrencinin herhangi bir dersin sınavında hissettiği kaygı olumsuz, süreç odaklı ve öğrencinin hissettiği kaygıyı azaltmak için bir şeyler yapmaya yönelmesi nedeniyle aktifleştirici bir 
duygu olarak betimlenebilir. Öğrencinin derste hissettiği can sıkıntısı ise olumsuz ve süreç odaklı, ancak öğrenciyi dersten davranışsal/zihinsel olarak uzaklaşmaya yönelttiği için pasifleştirici bir duygu olarak ifade edilebilir.

Bunlarla birlikte, başarı duygularının bilişsel bir değerlendirmenin sonucu olarak hissedildiklerinin vurgulanması da önemlidir (Pekrun, 2006). Örneğin, matematik dersiyle ilgili bir ödevin tamamlanması önemli görülüyorsa ve ödeve ilişkin algılanan kontrol yüksekse, ödevin tamamlanmasının olumlu duyguların (gurur vb.) hissedilmesine yol açması mümkündür. Bu da sırasıyla, bir sonraki göreve yönelik motivasyonu ve başarıyı etkileyebilmektedir. Nitekim başarı duyguları bağ-değerlerine, odak noktalarına ve etkinleştirme özelliklerine göre öğrencilerin öz-düzenleme becerileriyle, öğrenmeye yönelik motivasyonlarıly ve akademik başarılarıyla anlamlı düzeyde ilişkilendirilmektedir (Artino, Holmboe \& Durning, 2012; Daniels et al., 2009; Frenzel, Pekrun \& Goetz, 2007; Pekrun, Frenzel, Goetz \& Perry 2007). Hem bu nedenle, hem de öğrencilerin eğitim ortamlarında başarıyla ilgili olarak hissettikleri duyguların kapsamlı biçimde incelenmesine olanak sağlayan yegâne teori olması nedeniyle, bu çalışmada öğrencilerin İngilizce derslerinde hissettikleri başarıyla ilgili duygular, başarı duygularının kontrol-değer teorisi kapsamında incelenmiştir.

\section{Yöntem}

Araştırmada tarama yöntemi kullanılımışır. Araştırmanın deseni ise açımlayııı ilişkisel desendir (Exploratory Correlational Design). Söz konusu desen, araştırmanın odağında yer alan değişkenler arasındaki ilişkilere yönelik az sayıda kanıt bulunduğu ya da hiç bulunmadığı durumlarda kullanılan ve değiş̧enler arasındaki ilişkilerin tümevarıma dayalı bir bakış açısıyla incelenmesine olanak sağlayan bir desendir (Creswell, 2009; Fraenkel \& Wallen, 2006).

\section{Evren ve Örneklem}

Araştırmanın evrenini, 2014-2015 akademik yılında Hacettepe Üniversitesi ve Abant İzzet Baysal Üniversitesinde öğrenim gören toplam 3200 hazırlık sınıfı öğrencisi oluşturmuştur. Araştırmanın örneklemini ise evrenden rastgele seçilen toplam 475 öğrenci oluşturmuştur $(K ı z=200$; Erkek $=275)$. Öğrencilerin 234'ü Hacettepe Üniversitesinde, $241^{\prime} \mathrm{i}$ ise Abant i̇zzet Baysal Üniversitesinde öğrenim görmektedir. Öğrencilerin 204'ü Anadolu Lisesi, 176'sı Genel Lise, 33'ü Fen Lisesi, 44'ü Meslek Lisesi ve 18'i ise öğretmen lisesi mezunudur. Öğrencilerin yaş ortalaması 19.38'dir (SS = 1.00).

\section{Veri Toplama Araçları}

Bilgi Kaynakıı Merak Ölçeği: Öğrencilerin bilgiye yönelik merakları Litman (2008) tarafından geliştirilen ve Eren $(2009,2011)$ tarafından Türkçe 'ye uyarlanan Bilgi Kaynakıı Merak Ölçeği aracıllğıyla ölçülmüştür. Ölçme aracı, ilgi hissi olarak merak (Benim için yeni şeyler öğrenmek büyüleyicidir) ve yoksunluk hissi olarak merak (Problemler üzerinde, çözünceye kadar düşkünlük derecesinde çalışıım) şeklinde adlandırılan ve her biri beş madde içeren iki faktörden oluşmaktadır. Öğrencilerden, ölçme aracında yer alan maddeleri İngilizce derslerini akılda tutarak değerlendirmeleri istenmiştir. Öğrenciler ölçme aracında yer alan maddelere ilişkin görüşlerini, 1 (neredeyse asla) ile 4 arasında (neredeyse her zaman) arasında değişen değerlerle ve eşit aralıklarla sıralanan seçenekleri dikkate alarak belirtmişlerdir.

Başarı Duyguları Ölçeği: Öğrencilerin İngilizce derslerine yönelik olarak hissettikleri başarı duygularının ölçülmesi amacıyla, Pekrun, Goetz ve Perry (2005; Pekrun, Frenzel, Goetz \& Perry, 2007) tarafından geliştirilen ve komite yaklaşımı çerçevesinde (Dörnyei, 2010) araştırmacı tarafından Türkçe'ye uyarlanan Başarı Duyguları Ölçeği kullanılmıştır. Ölçme aracında yer alan maddeler matematik dersine yönelik olarak yazıımıştır. Ancak, bu araştırmanın odak noktasını İngilizce derslerinin oluşturması nedeniyle, maddelerdeki 'matematik dersi' ifadesi, 'Ingilizce dersi' ifadesiyle değiştirilmiştir. Başarı Duyguları Ölçeği derse, öğrenmeye ve sınava yönelik olmak üzere üç ayrı bölümden oluşmaktadır. Bu çalışmada İngilizce ders başarısına odaklanılması nedeniyle, Başarı Duyguları Ölçeğinin 'derse ilişkin duygular' bölümü kullanılmışır. Ölçeğin söz konusu bölümü altı faktörden ve toplam 19 maddeden oluşmaktadır. Bunlar; keyif (Dört madde: İngilizce dersini dört gözle beklerim), kaygı (Dört madde: İngilizce dersini düşündüğümde gergin hissederim), can sıııntısı (Üç madde: Ingilizce dersleri bence sıkıcıdır), sinirlilik (Dört madde: İngilizce dersi beni sinirlendirir), utanç (iki Madde: İngilizce dersinde bir şey söylediğimde kendimi utandırdığımı hissederim) ve gurur (iki Madde: ingilizce bilgimle gurur duyarım) faktörleridir. Öğrenciler ölçme aracında yer alan maddelere ilişkin görüşlerini, 1 (kesinlikle katılmıyorum) ile 5 
(kesinlikle katılıyorum) arasında değişen değerlerle ve eşit aralıklarla sıralanan seçenekleri dikkate alarak belirtmişlerdir.

Ölçme araçlarının, bu araştırmanın örneklemi kapsamında yapı geçerliklerinin sorgulanması amacıyla iki ayrı doğrulayıcı faktör analizi (DFA) gerçekleştirilmiştir. DFA sonucunda hem Başarı Duyguları Ölçeğinin $(\chi 2(137)=$ 361.09; CFI = .99; NNFI = .98; RMSEA = .06; SRMR = .03) hem de Bilgi Kaynaklı Merak ölçeğinin faktör yapılarının bu araştırmanın örnekleminden elde edilen verilerle iyi bir uyum gösterdiği saptanmıştır $(\chi 2(34)=87.72 ; \mathrm{CFI}=$ .97; NNFI = .96; RMSEA = .06; SRMR = .04) (Kline, 2011). Ayrıca, keyif $(\alpha=.87)$, kaygı $(\alpha=.89)$, can sıkıntısı $(\alpha=$ .89), sinirlilik $(\alpha=.80)$, utanç $(\alpha=.65)$ ve gurur $(\alpha=.67)$ faktörleri için hesaplanan Cronbach alfa katsayıları ile ilgi hissi olarak merak ( $\alpha=.68$ ) ve yoksunluk hissi olarak merak $(\alpha=.81$ ) faktörlerinin iç tutarlılık güvenirliklerine yönelik olarak hesaplanan alfa katsayıları da yeterli bulunmuştur.

\section{ingilizce ders başarısı:}

İngilizce ders başarısı için, öğrencilerin iki dönem süresince İngilizce derslerinde gerçekleştirilen sınavlardan aldıkları puanlarla, yılsonunda yapılan yeterlik sınavından aldıkları puanların 100'lük not sistemine göre hesaplanan ortalamaları kullanılmıştır.

\section{Veri Toplama Süreci ve Analizi}

Gerekli izinler alındıktan sonra, veriler birinci yazar tarafından ve öğretim elemanlarının uygun gördükleri zaman dilimlerinde toplanmıştır. Başarı Duyguları Ölçeği ve Bilgi Kaynaklı Merak Ölçeği araştırmanın amacını ve maddelere ilişkin görüşlerin nasıl belirtilmesi gerektiğine ilişkin açıklamaları içeren birer yönergeyle öğrencilere verilmiştir. Uygulama sürecinde öğrencilerden gelen sorular yanıtlanmış ve gerektiğinde ek açıklamalar yapılmıştır. Uygulama yaklaşık 20 dakika sürmüştür. Araştırmanın birinci sorusunun cevaplanması için bir dizi tek örneklem t testi gerçekleştirilmiştir. Araştırmanın ikinci sorusunun cevaplanması içinse sıfır-sıra (Pearson) korelasyon analizi gerçekleştirilmiştir. Araştırmanın üçüncü sorusunun yanıtlanması amacıyla da bilgiye yönelik merak faktörleri ile başarı duygularının (keyif, kaygı, can sıkıntısı, sinirlilik, utanç ve gurur) bağımsız ve İngilizce ders başarısının bağımlı değişken olarak belirlendiği çoklu regresyon analizi gerçekleştirilmiştir (Field, 2009). Regresyon analizinde, bu araştırmanın odak noktasında yer almamalarına rağmen, bağımlı değişkeni anlamlı düzeyde etkileyebilmeleri nedeniyle, demografik değişkenler de (yaş, cinsiyet, mezun olunan lise türü ve öğrenim görülen üniversite) regresyon analizine dâhil edilmiştir. Regresyon analizi sonucunda elde edilen bulguların daha güvenilir bir yaklaşımla sorgulanması amacıyla, İngilizce ders başarısıyla anlamlı düzeyde ilişkilendiği saptanan değişkenlerin bağımsız, İngilizce ders başarısının ise bağımlı değişken olarak belirlendiği yapısal bir model oluşturulmuştur. Söz konusu model, yapısal eşitlik modellemesi (YEM) analizi aracılığıyla sorgulanmıştır.

\section{Tek Örneklem $\mathbf{t}$ Testi Sonuçları}

\section{Bulgular}

Tablo 1'e bakıldığında, bilgiye yönelik merak ve başarı duygularıyla ilgili olarak hesaplanan t değerlerinin, ölçeklerin orta noktalarından hareketle hesaplanan test değerlerinden (Örneğin, kaygı faktörü için bu değer $4 \mathrm{x}$ 3 = 12'dir) anlamlı düzeyde farklılaşmadığı görülmektedir (tüm p değerleri > .05). Bunun anlamı, öğrencilerin Ingilizce derslerinde hissettikleri başarı duygularıyla bilgiye yönelik meraklarının orta düzeyde olduğudur.

Tablo 1.

Tek Örneklem t Testi Sonuçları.

\begin{tabular}{|c|c|c|c|c|c|}
\hline Değişken & Test Değeri & $\overline{\mathbf{x}}$ & SS & $t$ & $p$ \\
\hline İlgi Hissi Olarak Merak & 12.5 & 14.76 & 2.44 & .02 & .98 \\
\hline Yoksunluk Hissi Olarak Merak & 12.5 & 14.15 & 3.47 & .03 & .96 \\
\hline Keyif & 12 & 11.08 & 3.35 & .01 & .98 \\
\hline Kaygı & 12 & 11.70 & 3.88 & .03 & .97 \\
\hline Can Sıkıntısı & 9 & 10.04 & 3.99 & .02 & .98 \\
\hline Sinirlilik & 12 & 15.82 & 3.17 & .01 & .99 \\
\hline Utanç & 6 & 6.26 & 2.47 & .01 & .99 \\
\hline Gurur & 6 & 6.46 & 2.46 & .01 & .99 \\
\hline
\end{tabular}

\section{Korelasyon Analizi Sonuçları}

Bu araştırmanın örneklemi gibi görece büyük örneklemlerde, küçük korelasyon katsayılarının bile istatistiksel olarak anlamlı çıkabilmesi nedeniyle (Field, 2009), değişkenler arasındaki ilişkilerin 
yorumlanmasında korelasyon katsayılarının anlamlılık düzeylerinden çok, büyüklükleri dikkate alınmıştır. Tablo 2'de görüldüğü gibi, hem ilgi hissi olarak merak hem de yoksunluk hissi olarak merak, İngilizce ders başarısıyla olumlu yönde ve orta düzeyde ilişkilenmiştir. Başarı duyguları ise, bağ-değerlerine göre, İngilizce ders başarısıyla orta düzeyde ve seçici biçimde ilişkilenmiştir. Nitekim keyif ve gurur İngilizce ders başarısıyla orta düzeyde ve olumlu yönde ilişkilenirken, kaygı, can sıkıntısı, sinirlilik ve utanç İngilizce ders başarısıyla, büyüklükleri -.42 ile -.57 arasında değişen korelasyon katsayılarıyla orta düzeyde, ancak olumsuz yönde ilişkilenmiştir. Diğer taraftan, başarı duyguları ilgi hissi olarak merakla, büyüklükleri -.46 ile .46 arasında değişen korelasyon katsayılarıyla orta düzeyde ve seçici biçimde ilişkilenirken, yoksunluk hissi olarak merakla, büyüklükleri -.32 ile .33 arasında değişen korelasyon katsayılarıyla, görece zayıf ve seçici biçimde ilişkilenmiştir.

Tablo 2.

Korelasyon Analizi Sonuçları.

\begin{tabular}{|c|c|c|c|c|c|c|c|c|c|}
\hline Değişken & 1 & 2 & 3 & 4 & 5 & 6 & 7 & 8 & 9 \\
\hline 1. Ders Başarısı & - & & & & & & & & \\
\hline 2. İlgi Hissi Olarak Merak & .50 & - & & & & & & & \\
\hline 3. Yoksunluk Hissi Olarak Merak & .46 & .30 & - & & & & & & \\
\hline 4. Keyif & .48 & .46 & .33 & - & & & & & \\
\hline 5. Kaygı & -.54 & -.31 & -.31 & -.52 & - & & & & \\
\hline 6. Can Sıkıntısı & -.57 & -.46 & -.30 & -.57 & .58 & - & & & \\
\hline 7. Sinirlilik & -.56 & -.43 & -.32 & -.56 & .61 & .78 & - & & \\
\hline 8. Utanç & -.42 & -.43 & -.20 & -.48 & .43 & .71 & .63 & - & \\
\hline 9. Gurur & .54 & .46 & .29 & .64 & -.54 & -.68 & -.68 & .52 & - \\
\hline
\end{tabular}

Not: Tüm korelasyon katsayıları $p<.01$ düzeyinde anlamlıdır.

\section{Çoklu Regresyon Analizi Sonuçları}

Tablo 3'e bakıldığında, hem ilgi hissi olarak merakın hem de yoksunluk hissi olarak merakın İngilizce ders başarısını anlamlı düzeyde ve olumlu yönde yordadığı görülmektedir. Başarı duyguları arasında ise, yalnızca kaygı ve can sıkıntısı İngilizce ders başarısını anlamlı düzeyde, ancak olumsuz yönde yordamıştır. Üstelik bu sonuçlar, öğrenim görülen üniversite, mezun olunan lise türü, cinsiyet ve yaş değişkenlerinin etkilerinden de bağımsızdır (tüm $\mathrm{p}$ değerleri > .05). Nitekim demografik değişkenler İngilizce ders başarısına ilişkin toplam varyansın yalnızca \%1'ini açıklarken, bilgiye yönelik merak ve başarı duyguları toplam varyansın $\% 50$ 'sini açıklamışlardır.

Tablo 3.

Çoklu Regresyon Analizi Sonuçları.

\begin{tabular}{lrrrrrr}
\hline Değişkenler & B & S.H. & $\boldsymbol{\beta}$ & $\boldsymbol{t}$ & $\boldsymbol{p}$ & VIF \\
\hline Üniversite & .08 & .85 & .00 & .09 & .926 & 1.10 \\
Cinsiyet & .70 & .85 & .03 & .82 & .415 & 1.07 \\
Yaş & .21 & .43 & .02 & .49 & .624 & 1.09 \\
Lise türü & .01 & .38 & .00 & .02 & .988 & 1.05 \\
İlgi Hissi Olarak Merak & 1.17 & .20 & .23 & $5.78^{* * *}$ & .000 & 1.48 \\
Yoksunluk Hissi Olarak Merak & .81 & .13 & .22 & $6.25^{* * *}$ & .000 & 1.21 \\
Keyif & .02 & .17 & .01 & .13 & .898 & 2.02 \\
Kaygı & -.71 & .14 & -.22 & $-5.00^{* * *}$ & .000 & 1.80 \\
Can Sıkıntısı & -.50 & .19 & -.16 & $-2.59 *$ & .010 & 3.62 \\
Sinirlilik & -.34 & .23 & -.09 & -1.49 & .136 & 3.15 \\
Utanç & .21 & .24 & .04 & .85 & .394 & 2.19 \\
Gurur & .51 & .26 & .10 & 1.95 & .051 & 2.48 \\
\hline
\end{tabular}

${ }^{* * *} p<.001 ; * p<.05 ;$ Not: S.H. =Standart Hata; $\beta$ = Standartlaştırılmış Beta Katsayısı; VIF = Varyans Enflasyon Faktörü; VIF değerleri 5'ten küçüktür (Field, 2009).

\section{Yapısal Eşitlik Modellemesi Analizi Sonuçları}

Çoklu regresyon analizi sonucunda ortaya çıkan ilişkisel örüntünün sorgulanması amacıyla yapısal bir model oluşturulmuş (Şekil 1) ve bu model YEM aracılığıyla sorgulanmıştır. YEM analizi sonucunda, söz konusu modelin bu araştırmanın örnekleminden elde edilen verilerle iyi bir uyum sergilediği saptanmıştır $\left(\chi^{2}(126)=313.70 ; C F I=\right.$ 
.98; NNFI = .97; RMSEA = .06; SRMR = .04). YEM analizi sonuçları, regresyon analizi aracıllı̆ıyla elde edilen sonuçlarla oldukça benzer biçimde, ilgi hissi olarak merak, yoksunluk hissi olarak merak, can sıkıntısı ve kaygı değişkenlerinin İngilizce ders başarısını anlamlı düzeyde ve seçici biçimde yordadığını göstermiştir.

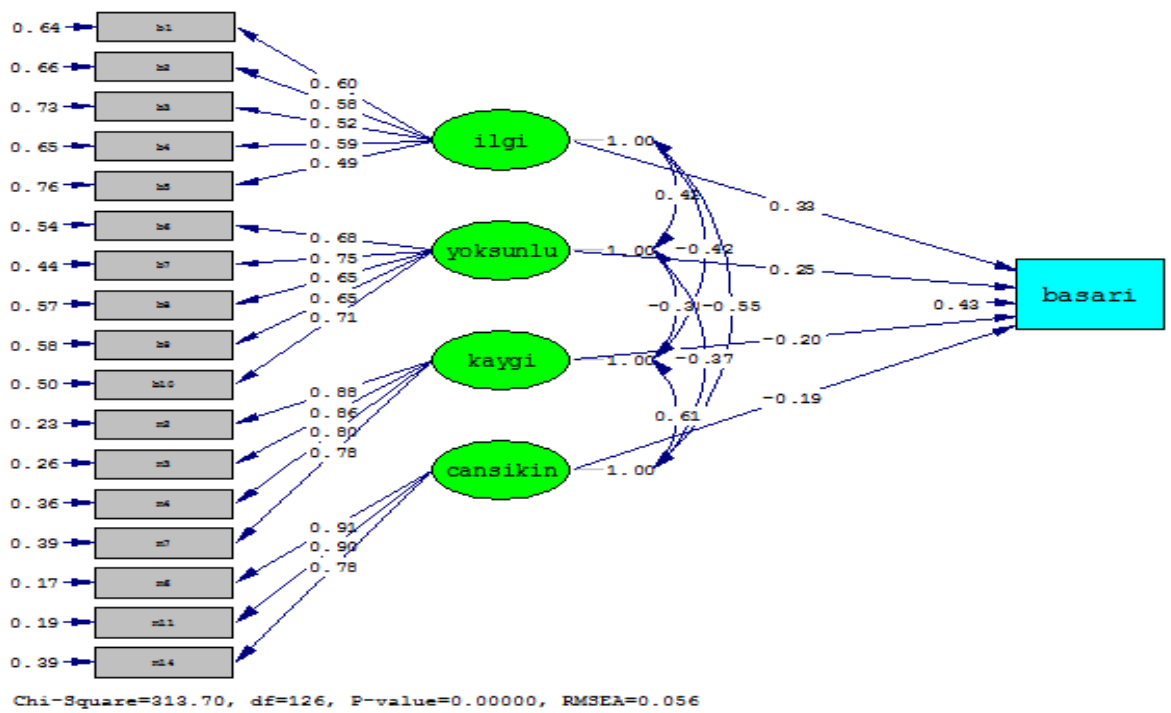

Şekil 1: İngilizce ders başarısının yordayıcılarına ilişkin yapısal model.

Tartışma, Sonuç ve Öneriler

Tek örneklem t testleri aracılığıyla elde edilen sonuçlar, hazırlık sınıfı öğrencilerinin İngilizce derslerinde hissettikleri olumlu ve olumsuz başarı duygularıyla bilgiye yönelik meraklarının orta düzeyde olduğunu göstermiştir. Araştırmanın bu bulgusu, öğrencilerin İngilizce derslerinde başarıyla ilgili birçok olumlu ve olumsuz duyguyu hissettiklerinin bir göstergesi olarak değerlendirilebilir. İngilizce derslerinin, tıpkı diğer dersler gibi, öğrencilerin hem olumlu (keyif alma, gurur duyma vb.) hem de olumsuz duyguları (can sıkıntısı, kaygı) hissetmelerine yol açabilen uyaranlar sağlayan öğrenme ortamları oldukları düşünüldüğünde (örneğin, İngilizce dersinin yaklaşmakta olan sınavının kaygıya yol açması, derste doğru olarak yanıtlanan bir sorunun öğrenciyi mutlu etmesi, dersteki monotonluğun can sıkıntısına yol açması vb.), bu bulgunun şaşırtıcı olmadığı söylenebilir. Nitekim iletişim etkinliklerinin yoğun olarak kullanıldığı öğrenme ortamları olan İngilizce derslerinde, çeşitli iletişim etkinliklerinin (sözlü, yazılı vb.) sonucu olarak verilen dönütlerin (başarıyla ilgili olumlu/olumsuz dönütler vb.), olumlu ve/veya olumsuz başarı duygularının hissedilmesine neden olması beklenebilir. Bu bulgu Goetz, Frenzel, Hall ve Pekrun'un (2008), başarı duygularının akademik ortamlarda sıklıkla hissedilen duygular olduğuna yönelik bulgularıyla da paraleldir. Tek örneklem t testleri aracılığıyla elde edilen sonuçlar, öğrencilerin Ingilizce derslerinde hem yoksunluk hissi olarak merakı hem de ilgi hissi olarak merakı deneyimlediklerini de göstermiştir. Derslerde gerçekleşen iletişim süreçlerinin (dönüt verme vb.) yalnızca duyguları değil, bilgiye yönelik merakı da uyarabileceği dikkate alındığında (Kang et al., 2009), araştırmanın bu bulgusu anlaşılabilir bir görünüme kavuşmaktadır.

Dikkat çekici bir diğer bulgu ise, başarı duygularıyla bilgiye yönelik merakın İngilizce derslerinde öğrenciler tarafından güçlü ya da zayıf biçimde değil, orta düzeyde hissedilmeleridir. Araştırmanın bu bulgusu, İngilizce derslerindeki etkinliklerin/görevlerin (sınavlar, ödevler vb.) öğrenciler tarafından zor ya da kolay olarak algılanmamalarıyla ilgili olabilir. Örneğin, kelime öğretiminde grafik düzenleyicilerin rolünün incelendiği çalışmasında îlter (2016), olumlu başarı duygularının grafik düzenleyicilerin kullanıldığı deney grubunda, kontrol grubuna göre, daha fazla hissedildiğini saptamıştır. Bilgiye yönelik merak ile İngilizce ders başarısına ilişkin bu bağlamda gerçekleştirilmiş bir çalışma bulunmamasına rağmen, üç boyutlu görseller gibi bazı materyallerin uygun öğretim teknikleriyle (iletişim oyunları vb.) kullanılmasının, öğrencilerde ilgi hissi olarak merakı uyandırması beklenebilir. Ayrıca, konuya ilişkin önceki bilgilerle yeni bilgiler arasında algılanan bilgi eksikliğinin öğrencilerde yaratacağı yoksunluk hissine bağlı olarak, bu ve benzeri materyallerin İngilizce derslerinde yoksunluk hissi olarak merakı uyandırması da beklenebilir.

Korelasyon analizi aracılığıyla elde edilen sonuçlar, başarı duygularının İngilizce ders başarısıyla anlamlı düzeyde ve seçici biçimde ilişkilendiklerini ortaya koymuştur. Sonuçlar ayrıca, ilgi hissi olarak merak ve yoksunluk hissi olarak merakın İngilizce ders başarısıyla anlamlı düzeyde ve olumlu yönde ilişkilendiğini de 
göstermiştir. Duyguların ve bilgiye yönelik merakın algılanan yetenek, öz-yeterlik, akademik başarı ve akademik benlik gibi değişkenlerle ilişkili olduğu (Putwain ve Deveney, 2009) ve öğrenci davranışlarının ve ders başarısının açıklanmasındaki rolleri dikkate alındığında (Berlyne, 1954; Litman, 2008, 2010; Loewenstein, 1994; Skinner, Furrer, Marchand \& Kindermann, 2008), bu değişkenlerin öğrencilerin İngilizce ders başarısıyla neden ilişkilendiği anlaşılabilir. Nitekim korelasyon analizi aracılığıyla elde edilen sonuçlar, hem bilgiye yönelik merakın bilişsel etkinlik düzeyleriyle (Tamdogon, 2006), öğrenmeyle (Day, 1982) ve akademik başarıyla olumlu yönde ve güçlü biçimde ilişkilendiğine yönelik bulguların elde edildiği araştırmalarla, hem de olumsuz duyguların (kaygı vb.) akademik başarıyla olumsuz yönde, olumlu duyguların ise (örneğin gurur) akademik başarıyla olumlu yönde ilişkilendiğine yönelik bulgular Pekrun'un (2006) çalışmasıyla tutarlıdır.

Diğer taraftan, korelasyon analizi aracılı̆̆ıyla elde edilen sonuçlar, başarı duygularının ilgi hissi olarak merakla olan ilişkilerinin, yoksunluk hissi olarak merakla olan ilişkilerine göre daha güçlü olduğunu da göstermiştir. Bunun bir olası nedeni, ilgi hissi olarak merakın, yoksunluk hissi olarak meraka göre daha olumlu bir duyuşsal içeriğe sahip olması olabilir (Litman, 2008). Bir diğer olası nedeni ise, ilgi gibi olumlu bir hissin, yoksunluk gibi olumsuz bir hisse göre, öğrencilerin İngilizce öğrenmeye yönelik motivasyonlarını daha fazla artırması olabilir. Bu açıklama ilginin güçlü bir motivasyon kaynağı olduğu gerçeğiyle de tutarlıdır (Hidi, 2006). Bu da sırasıyla, öğrencilerin İngilizce derslerinde olumlu duyguları daha fazla, olumsuz duyguları ise daha az hissetmelerine yol açabilir. Ancak, bu araştırmanın ilişkisel bir desenden hareketle gerçekleştirilmesi ve kesitsel verilere dayalı olması, bu açıklamayı kısmen de olsa tartışmalı hale getirmektedir. Dolayısıyla, söz konusu açıklamanın gelecekte yapılacak araştırmaları gerektirdiği söylenebilir.

Çoklu regresyon analizi sonuçları ile YEM analizi sonuçları, can sıkıntısı ve kaygı duygularının İngilizce ders başarısını anlamlı düzeyde yordadığını göstermiştir. Olumlu başarı duygularının değil, can sıkıntısı ve kaygı gibi iki olumsuz başarı duygusunun İngilizce ders başarısını yordamasının dikkat çekici olduğu ifade edilebilir. Bu sonuç, araştırmada yalnızca iki olumlu başarı duygusuna karşı (keyif ve gurur), dört olumsuz başarı duygusunun (utanç, can sıkıntısı, sinirlilik, kaygı) dikkate alınmış olmasına bağlı olarak açıklanabilir. Nitekim bu durum, olumlu başarı duygularının İngilizce ders başarısı üzerindeki etkilerinin, olumsuz başarı duyguları tarafından baskılanmasına yol açabilir. Önemli olarak, demografik değişkenlerin İngilizce ders başarısına ilişkin toplam varyansın yalnızca \%1'ini açıklaması ve bu değişkenler arasında mezun olunan lise türlerinden biri olarak Anadolu liselerinin de yer alması düşündürücüdür. Çünkü Anadolu liselerindeki yabancı dil derslerinin saatleri, diğer liselere göre daha fazladır. Araştırmanın bu sonucu, Ingilizce derslerindeki başarının ders saatlerinin niceliğinden çok, niteliğine bağlı olduğu şeklinde yorumlanabilir. Ancak bu araştırmada İngilizce derslerinin niteliğine odaklanılmamış olması, bu yorumu mantıklı olmasına rağmen tartışmalı hale getirmektedir. Dolayısıyla, bu yorumun gelecekte yapılacak araştırmaları gerektirdiği açıktır.

İngilizce ders başarısının neden utanç ve sinirlilik tarafından değil de can sıkıntısı ve kaygı tarafından anlamlı düzeyde yordandığı ise, can sıkıntısının olumsuz bir duygu olmasının yanında, pasifleştirici bir duygu olma özelliğiyle (öğrencileri öğrenme ortamından davranışsal/zihinsel anlamda uzaklaştıran bir duygu olma özelliği) açıklanabilir. Can sıkıntısının söz konusu özelliği, sinirlilik ve utanç gibi aktifleştirici olumsuz duygulardan farklı olarak, sınıflar gibi eğitim ortamlarında saptanmasını güçleştirmekte (Pekrun, 2006) ve bu da can sıkıntısının başarıyı olumsuz yönde etkileme olasılığını artırmaktadır (Bridgeland, Dilulio \& Morison, 2006). Bu açıklama, can sıkıntısının ders başarısıyla anlamlı düzeyde ve olumsuz yönde ilişkilendiğinin saptandığı araştırmalarla tutarlıdır (Pekrun, Goetz, Daniels, Stupnisky \& Perry, 2010). Kaygı değişkeni ise can sıkıntısının aksine, aktifleştirici bir duygudur. Ancak kaygının dersin akışını bozucu davranışlara yol açma olasılığı, beklenti odaklı bir duygu olması nedeniyle, sinirlilik ve utanç gibi diğer olumsuz ve aktifleştirici duygulardan daha düşük olabilir. Bu nedenle kaygı, tıpkı can sıkıntısı gibi, eğitim ortamlarında saptanması güç tepkilere neden olabilir. Bir öğrencinin yakın gelecekte yapılacak olan bir dersin sınavından başarısız olma beklentisinin yarattığı kaygıyı azaltmak için derse hazırlanmak yerine başka konulara odaklanması, hayal kurarak zihinsel anlamda dersten uzaklaşması, bu gibi tepkilere ilişkin örnekler olarak verilebilir. Bu da sırasıyla, kaygının diğer olumsuz duygulara göre İngilizce ders başarısı üzerindeki olumsuz etkisini artırabilir. Bu yorumlar, kaygının yabancı dil ders başarısıyla ilişkili olarak incelendiği eğitim araştırmalarından elde edilen sonuçlarla da tutarlıdır (Batumlu \& Erden, 2007; Salim, 2004; Worde, 2003).

Regresyon analizi ve YEM analizi aracılığıyla elde edilen sonuçlar ayrıca, ilgi hissi olarak merak ve yoksunluk hissi olarak merakın İngilizce ders başarısını anlamlı düzeyde yordadı̆̆ını da göstermiştir. Bilgiye yönelik söz konusu merak türleri farklı hislerle betimlenmelerine rağmen, yeni bilgi elde etme arzusu ekseninde birleşen ortak bir içeriğe sahiptirler (Litman, 2008). Üstelik konuyla ilgili alanyazında, her iki merak türünün de akademik başarıyla/ders başarısıyla olumlu yönde ve güçlü biçimde ilişkilendiğine yönelik bulgular da mevcuttur (Eren \& 
Coşkun, 2016; Serin, 2010). Dolayısıyla, söz konusu merak türlerinin İngilizce ders başarısını anlamlı düzeyde ve olumlu yönde yordamaları beklenebilir.

Araştırmanın yukarıda tartışılan bulgularından hareketle üç önemli sonuç çıkarılabilir. Birincisi, hazırlık sınıflarındaki İngilizce derslerinin, olumlu ve olumsuz başarı duygularından ve bilgiye yönelik meraktan yoksun ortamlar olmadığıdır. İkincisi, başarı duygularının ve bilgiye yönelik merakın, İngilizce ders başarısıyla anlamlı düzeyde ve seçici biçimde ilişkilendikleridir. Üçüncüsü ve daha önemlisi, özellikle can sıkıntısı ve kaygı gibi olumsuz başarı duygularının İngilizce ders başarısını olumsuz yönde, ilgi hissi olarak merakla yoksunluk hissi olarak merakın ise Ingilizce ders başarısını olumlu yönde yordadığıdır.

Dolayısıyla, hazırlık sınıflarında İngilizce derslerine giren öğretim elemanları, öğrencilerinin derslerde gurur duyma ve keyif alma gibi olumlu duygularla birlikte kaygı, can sıkıntısı, utanç, sinirlilik gibi olumsuz duyguları da hissettiklerini ve bunlar arasında özellikle can sıkıntısı ve kaygının İngilizce ders başarısıyla olumsuz yönde ilişkilendiğini dikkate almalıdırlar. Buna göre, öğretim elemanlarının İngilizce derslerinde kaygıyı (örneğin, olumlu ve destekleyici bir sınıf iklimi oluşturma) ve can sıkıntısını azaltmaya yönelik girişimlerinin (örneğin, can sıkıntısının azaltılmasında etkili olan bilişsel yaklaşma stratejileri konusunda öğrencileri bilgilendirme, (Nett, Goetz \& Daniels, 2010), ders başarısının artırılmasına katkı sağlayacağı söylenebilir. Bununla birlikte, öğretim elemanları derslerinde yalnızca kaygı ve can sıkıntısı gibi olumsuz duyguların hissedilme düzeylerini azaltarak değil, bilgiye yönelik merakı uyandırabilecek etkinlikler aracılığıyla da öğrencilerinin ingilizce ders başarısını artırabilirler. Bunlar, görsel (ilgi çekici statik ve/veya dinamik görseller vb.) ve işitsel (müzik vb.) uyaranlar içeren etkinlikler olabileceği gibi (Berho \& Defferding, 2005), durumsal ilgiyi artırmaya yönelik hayal etkinlikleri de olabilir (Doğru \& Eren, 2016). Yukarıda özetlenen sonuçlar, eğitim bilimsel anlamda bu ve benzeri önemli önerilerde bulunma olanağı sağlamasına rağmen, bu araştırmanın yalnızca iki farklı üniversitenin İngilizce hazırlık sınıflarında öğrenim gören öğrencileri içermesi, İngilizce ders başarısının öğretmenler tarafından hazırlanan sınavların sonuçlarına dayalı olarak değerlendirilmesi, görece küçük bir örneklemden ve ilişkisel bir desenden hareketle gerçekleştirilmesi gibi sınırlılıkları nedeniyle, gelecekte yapılacak araştırmalarda dikkatle yorumlanmalıdır. Dolayısıyla, çok sayıda üniversitenin yer aldığı, daha büyük örneklemlerden hareketle gerçekleştirilen ve İngilizce ders başarısının standart başarı testlerinin sonuçlarına dayalı olarak değerlendirildiği araştırmalardan elde edilecek bulgular, bu araştırmadan elde edilen sonuçların genellenebilirliğinin sorgulanmasına katkı sağlayabilir. Ayrıca, bilgiye yönelik merakın ya da başarı duygularının manipüle edileceği deneysel araştırmaların sonuçları, nedensellik çıkarımına imkân sağlamaları nedeniyle, bu araştırmada elde edilen ilişkisel çerçeveyi genişletebilir.

\section{Bilgilendirme}

Bu çalışma birinci yazarın ikinci yazar danışmanlığında hazırlanan yüksek lisans tezinden üretilmiştir. Bu çalışmanın bir bölümü 26. Uluslararası Eğitim Bilimleri Kongresinde bildiri olarak sunulmuştur (20-23 Nisan 2017, Antalya, Türkiye). 


\section{References}

Artino, A., Holmboe, E., \& Durning, S. (2012) Control-value theory: Using achievement emotions to improve understanding of motivation, learning, and performance in medical education. Medical Teacher, 34, 148160.

Artino, A. J., \& Stephens, J. M. (2007). Bored and frustrated with online learning? Understanding achievement emotions from a social cognitive, control-value perspective. Paper presented at the annual meeting of the Northeastern Educational Research Association, Rocky Hill, Connecticut, CT, USA.

Bağçeci, B. (2004). Ortaöğretim kurumlarında ingilizce öğretimine ilişkin öğrenci tutumları (Gaziantep ili örneği). Paper presented at the 13th National Educational Sciences Congress, İnönü University, Malatya.

Batumlu, D. Z., \& Erden, M. (2007) Yıldız teknik üniversitesi yabancı diller yüksek okulu hazırlık öğrencilerinin yabancı dil kaygıları ile İngilizce başarıları arasındaki ilişki. Journal of Theory and Practice in Education, 3, 2438.

Berho, D. L., \& Defferding, V. (2005). Communication, culture, and curiosity: Using target-culture and studentgenerated art in the second language classroom. Foreign Language Annals, 38(2), 271-277.

Berlyne, D. E. (1954). A theory of human curiosity. British Journal of Psychology, 45, 180-191.

Berlyne, D. E. (1960). Conflict, arousal, and curiosity. New York, NY: McGraw-Hill.

Bridgeland, J. M., Dilulio, J. J., \& Morison K. B. (2006). The silent epidemic: Perspectives of high school dropouts. A report by Civic Enterprises in association with Peter D. Hart Research Associates for the Bill \& Melinda Gates Foundation.

Coleman, T. C. (2014). Positive emotion in nature as a precursor to learning. International Journal of Education in Mathematics, Science and Technology, 2(3), 175-190.

Creswell, J. W. (2009). Research design: Qualitative, quantitative, and mixed methods approaches (3rd ed.). Los Angeles, CA: Sage.

Daniels, L. M., Stupnisky, R. H., Pekrun, R., Haynes, T. L., Perry, R. P., \& Newall, N. E. (2009). A longitudinal analysis of achievement goals: From affective antecedents to emotional effects and achievement outcomes. Journal of Educational Psychology, 101, 948-963.

Day, H. I. (1982). Curiosity and the interested explorer. Performance and Instruction, 21, 19-22.

Doğru, E., \& Eren, A. (2016). Hayal etkinliklerinin İngilizce derslerindeki durumsal ilgi ve başarı üzerindeki etkilerinin incelenmesi. Hacettepe Üniversitesi Eğitim Bilimleri Enstitüsü Eğitim Araştırmaları Dergisi, 2(2), 78-97.

Dörnyei, Z. (2010). Questionnaires in second language research: Construction, administration, and processing. London: Routledge.

Education First-English Proficiency Index (2016). Retrieved May 01, 2017, from http://www.ef.com.tr/epi/.

Eren, A. (2009). Examining the relationship between epistemic curiosity and achievement goals. Eurasian Journal of Educational Research, 36, 129-144.

Eren, A. (2011). Prospective teachers' general epistemic curiosity and domain-specific epistemic curiosity: The mediating role of perceived instrumentality. In R. M. Teixeira (Ed.), Higher education in a state of crisis (pp. 163-183). New York, NY: Nova Science Publishers.

Eren, A., \& Coşkun H. (2016). Students' level of boredom, boredom coping strategies, epistemic curiosity, and graded performance. Journal of Educational Research, 109, 574-588.

Educational Testing Service (2016). Retrieved March 24, 2016, from http://www.ets.org/s/toefl/pdf/94227_unlweb.pdf.

Field, A. P. (2009). Discovering statistics using SPSS. London: Sage.

Fowler, H. (1965). Curiosity and exploratory behavior. New York, NY: Macmillan.

Fraenkel, J. R., \& Wallen, N. E. (2006). How to design and evaluate research in education (6th ed.). New York, NY: McGraw-Hill.

Frenzel, A. C., Pekrun, R., \& Goetz, T. (2007). Girls and mathematics - a "hopeless" issue? A control-value approach to gender differences in emotions towards mathematics. European Journal of Psychology of Education, 22, 497-514. 
Goetz, T., Frenzel, A., Hall, N., \& Pekrun, R. (2008). Antecedents of academic emotions: Testing the internal/external frame of reference model for academic enjoyment. Contemporary Educational Psychology 33, 9-33.

Hidi, S. (2006). Interest: A unique motivational variable. Educational Research Review, 1, 69-82.

Iilter, i. (2016). The power of graphic organizers: Effects on students' word-learning and achievement emotions in social studies. Australian Journal of Teacher Education, 41, 42-64.

Kang, M. J., Hsu, M., Krajbich, I., Loewenstein, G., McClure, S., Wang, J. T., \& Camerer, C. (2009). The wick in the candle of learning: Epistemic curiosity activates reward circuitry and enhances memory. Psychological Science, 20(8), 963-973.

Kline, R. B. (2011). Principles and practice of structural equation modeling. New York, NY: Guilford Press.

Koru, S., \& Åkesson, J. (2011). Türkiye'nin Ingilizce açığı. The Economic Policy Research Foundation of Turkey. Retrieved from http://www.tepav.org.tr/upload/files/13297228036. Turkiye_nin_Ingilizce_Acigi.pdf.

Litman, J. A. (2005). Curiosity and the pleasures of learning: Wanting and liking new information. Cognition and Emotion, 19, 793-814.

Litman, J. A., \& Jimerson, T. L. (2004). The measurement of curiosity as a feeling of deprivation. Journal of Personality Assessment, 82, 147-157.

Litman, J. A., Hutchins, T. L., \& Russon, R. K. (2005). Epistemic curiosity, feeling-of- knowing, and exploratory behaviour. Cognition and Emotion, 19, 559-582.

Litman, J. A. (2008). Interest and deprivation dimensions of epistemic curiosity. Personality and Individual Differences, 44, 1585-1595.

Litman, J. A. (2010). Relationships between measures of I- and D-type curiosity, ambiguity tolerance, and need for closure: An initial test of the wanting-liking model of information-seeking. Personality and Individual Differences, 48, 397-402.

Loewenstein, G. (1994). The psychology of curiosity: A review and reinterpretation. Psychological Bulletin, 116, 75-98.

Lopez, M. G. M., \& Aguilar A. P. (2013). Emotions as learning enhancers of foreign language learning motivation. Profile, 15, 109-124.

Nett, U. E., Goetz, T., \& Daniels, L. (2010). What to do when feeling bored? Students' strategies for coping with boredom. Learning and Individual Differences, 20(6), 626-638.

Özçetin, N., \& Eren, A. (2010). The effects of perceived instrumentality and future time perspective on students' graded performance and attitudes regarding English class. International Journal on New Trends in Education and Their Implications, 1, 40-47.

Pekrun, R. (2006). The control-value theory of achievement emotions: Assumptions, corollaries, and implications for educational research and practice. Educational Psychology Review, 18, 315-341.

Pekrun, R., Frenzel, A., Goetz, T., \& Perry, R. P. (2007). The control-value theory of achievement emotions: An integrative approach to emotions in education. In P. A. Schutz, R. Pekrun (Eds.), Emotion in education (pp. 13-36). San Diego, CA: Academic Press.

Pekrun, R., Goetz, T., Daniels, L. M., Stupnisky, R. H., \& Perry, R. P. (2010). Boredom in achievement settings: Control-value antecedents and performance outcomes of a neglected emotion. Journal of Educational Psychology, 102, 531-549.

Pekrun, R., Goetz, T., \& Perry, R. P. (2005). Academic Emotions Questionnaire (AEQ). User's manual. Department of Psychology, University of Munich.

Pekrun, R., Goetz, T., Titz, W., \& Perry, R. P. (2002). Academic emotions in students' self-regulated learning and achievement: A program of qualitative and quantitative research. Educational Psychologist, 37, 91-106.

Pintrich, P., \& Schunk, D. (1996). Motivation in education: Theory, research and applications. Englewood Cliffs, NJ: Prentice-Hall.

Putwain, D., \& Deveney, C. (2009). Examination performance using an expanded integrated hierarchical model of test emotions and achievement goals. Psychology Teaching Review, 15, 18-31.

Renner, B. (2006). Curiosity about people: The development of a social curiosity measure in adults. Journal of Personality Assessment, 87, 305-316. 
Saracaloğlu, A. S. (1995). Üniversite öğrencilerinin yabancı dile yönelik tutumları. Buca Eğitim Fakültesi Dergisi,3(7), 73-91.

Serin, G. (2010). Illköğretim 7. sınıf öğrencilerin fene karşı meraklarının incelenmesi. Mustafa Kemal Üniversitesi Sosyal Bilimler Enstitüsü Dergisi, 7, 237-252.

Skinner E. A., Furrer C. J., Marchand G., \& Kindermann T. (2008). Engagement and disaffection in the classroom: Part of a larger motivational dynamic? Journal of Educational Psychology, 100(4), 765-781.

Sorrentino, R. M., \& Roney, C. R. J. (2000). The uncertain mind: Individual differences in facing the unknown. Philadelphia, PA: Psychology Press.

Spielberger, C. D., \& Starr, L. M. (1994). Curiosity and exploratory behavior. In H. F. O’Neil Jr., \& M. Drillings (Eds.), Motivation: Theory and research (pp. 221-243). Hillsdale, NJ: Lawrence Erlbaum.

Tamdogon, O. G. (2006). Creativity in education: Clearness in perception, vigorousness in curiosity. Education for Information, 24, 139-151.

Worde, R. (2003). Students' perspectives on foreign language anxiety. Inquiry, 8, 1-15.

Yükseköğretim Kurulu (2007). Türkiye'nin yükseköğretim stratejisi. Ankara: Yükseköğretim Kurulu. 